Shinichi Inomata MD, Toshiaki Nishikawa MD, Shinichi Kihara MD, Yuichiro Akiyoshi MD

\section{Enhancement of pressor response to intravenous phenyl- ephrine following oral clonidine medication in awake and anaesthetized patients}

cation, $5 \mu \mathrm{g} \cdot \mathrm{kg}^{-1}$, augments the pressor responses to phenylephrine $2 \mu \mathrm{g} \cdot \mathrm{kg}^{-1}$ iv in awake and anaesthetized patients. These results suggest that the enhancement of the pressor responses to phenylephrine following oral clonidine may be due to clonidine-induced potentiation of $\alpha_{1}$-adrenoceptor-mediated vasoconstriction. This implies that restoration of blood pressure can be achieved effectively by phenylephrine in hypotensive patients with clonidine premedication.

La clonidine, un agoniste $\alpha_{Z}$ adrénergique exagère la réponse vasopressive à l'éphédrine ì. Si cet effet est en partie dû̀ à la potentialisation de la vasoconstriction à médiation $\alpha_{I^{-}}$ adrénergique induite par la clonidine, on peut assumer que la clonidine exagérera aussi l'effet vasopressur de la phényléphrine, cet autre agoniste $\alpha_{1}$-adrénergique. Les auteurs ont étudié les réponses hémodynamiques provoquées par la phényléphrine iv chez 80 patients qui avaient été prémédiqués à la clonidine à la dose approximative de $5 \mu \mathrm{g} \cdot \mathrm{kg}^{-1}$ po (groupe clonidine, $n=40$ ) ou qui n'avaient pas reçu de clonidine (groupe contrôle, $n=40$ ). Chaque groupe a été subdivisé en deux sous-groupes: sujets éveillés $(n=20)$ ou sujets anesthésiés à l'enflurane et au protoxyde d'azote en oxygène $(n=$ 20). Les mesures hémodynamiques ont été effectuées à une min d'intervalle pendant dix minutes après lïnjection d'un bolus de phényléphrine $2 \mu \mathrm{g} \cdot \mathrm{kg}^{-1}$. L'ordre de grandeur de l'augmentation maximale de la pression moyenne pour le groupe clonidine (sujets éveillés $26 \pm 7 \%$ (moyenne $\pm S D$ ), sujets anesthésiés $32 \pm 15 \%)$ est plus élevé $(P<0,05)$ que pour le groupe contrôle (sujets éveillés $13 \pm 7 \%$, sujets anesthésiés $18 \pm 7 \%$ ). Cependant, l'effet vasopresseur de la phényléphrine n'est pas différent entre patients éveillés ou anesthésiés de chaque groupe. En prémédication, la clonidine $5 \mu \mathrm{g} \cdot \mathrm{kg}^{-1}$ po augmente l'effet vasopresseur de la phényléphrine $2 \mu \mathrm{g} \cdot \mathrm{kg}^{-I}$ iv aussi bien chez les patients éveillés qu'anesthésiés. Ces résultats portent à croire que l'exagération des réponses pressives provoquées par la phényléphrine après la clonidine po pourraient être causées par 
la potentialisation de la vasoconstriction à médiation $\alpha_{l_{-}}$ adrénergique. On peut donc rétablir la pression artérielle efficacement avec la phényléphrine chez le patient hypotendu prémédiqué à la clonidine.

Although clonidine, an $\alpha_{2}$-adrenoceptor agonist, has recently been used as preanaesthetic medication to reduce opioid or volatile anaesthetic requirements and to improve cardiovascular stability, ${ }^{1-3}$ there is only limited clinical information regarding the interactions between $\alpha_{2}$-adrenergic agonists and other sympathomimetic or parasympatholytic agents. ${ }^{4-7}$ Our recent studies demonstrated that oral clonidine preanaesthetic medication 5 $\mu \mathrm{g} \cdot \mathrm{kg}^{-1}$ augments the pressor responses to intravenous ephedrine $0.1 \mathrm{mg} \cdot \mathrm{kg}^{-1}$ in awake or anaesthetized patients. ${ }^{4,5}$ Since ephedrine exerts its pressor effect through both direct and indirect actions, the precise mechanism for this enhanced pressor effect of ephedrine following clonidine medication is too complicated to be fully elucidated in clinical settings. However, increased vascular activity to ephedrine and/or norepinephrine has been proposed as one of the underlying mechanisms., 4

If clonidine potentiated postjunctional $\alpha_{1}$-adrenoceptor mediated vasoconstriction, the pressor effect of phenylephrine, an $\alpha_{1}$-adrenergic agonist, would be augmented following clonidine medication. According to Guthrie and Kotchen, ${ }^{8}$ the dose of phenylephrine required to increase systolic blood pressure by $20 \mathrm{mmHg}$ was less in hypertensive patients receiving oral clonidine than in those receiving placebo. On the other hand, clonidine has been shown to antagonize competitively the positive inotropic effect of phenylephrine that is mediated via $\alpha$ adrenoceptors in isolated papillary muscles of the rabbit heart. ${ }^{9}$ Furthermore, volatile anaesthetics have been demonstrated to modulate the effect of $\alpha_{1^{-}}$or $\alpha_{2-}$ adrenoceptor-mediated pressor responses in animal experiments. ${ }^{10,11}$

There are no data concerning the interaction between clonidine po and phenylephrine $i$ in normotensive subjects, and the effect of general anaesthesia upon the interaction between these two agents. The aim of the study was to examine whether the pressor effect of phenylephrine $i v$ would be altered after clonidine medication po in awake and anaesthetized humans.

\footnotetext{
Methods

Eighty normotensive surgical patients, ASA physical status $\mathrm{I}$, ranging in age from 27 to $59 \mathrm{yr}$, and scheduled to have general anaesthesia for surgical procedures, were selected for this study. The study protocol was approved by our Clinical Investigation Committee. Informed consent was obtained from each patient. No patient had any
}

cardiopulmonary disorders, none was taking any medication affecting cardiovascular function or had received either caffeine or nicotine in the $12 \mathrm{hr}$ prior to study.

The patients were randomly allocated to the different groups. Forty patients received clonidine (Catapres ${ }^{\circledR}$, Boehringer Ingelheim \& Tanabe), approximately 5 $\mu \mathrm{g} \cdot \mathrm{kg}^{-1}$ po, $1.5-2 \mathrm{hr}$ before arrival in the operating room (clonidine group). Since clonidine is available only in tablets of $75 \mu \mathrm{g}$ or $150 \mu \mathrm{g}$ in Japan, doses were determined by choosing the dose closest to half a tablet, $37.5 \mu \mathrm{g}$ multiples. The remaining 40 patients received no medication (control group). An 18-gauge catheter was inserted for infusion of lactated Ringer's solutiojn at a rate of $10 \mathrm{ml} \cdot \mathrm{kg}^{-1} \cdot \mathrm{hr}^{-1}$ during the study.

After a stable haemodynamic state was obtained in each patient, positioned supine with a pillow, for several minutes, phenylephrine $2 \mu \mathrm{g} \cdot \mathrm{kg}^{-1} \dot{n}$ was administered over five seconds in 20 awake patients each of both groups. Phenylephrine hydrochloride solution (Kowa, Nagoya, Japan) was diluted to a concentration of 20 $\mu \mathrm{g} \cdot \mathrm{ml}^{-1}$. Blood pressure (BP) and heart rate (HR) were measured at one-minute intervals for ten minutes after injection of phenylephrine, while lead II of the electrocardiogram (ECG; Life Scope $12^{\mathrm{TM}}$, Nihon Kohden, Tokyo, Japan) was continuously monitored. The BP was measured oscillometrically with a BP monitoring device (Life Scope $12^{\mathrm{TM}}$, Nihon Kohden, Tokyo), and HR was determined as an average of every four seconds from the ECG monitor.

In the remaining $\mathbf{4 0}$ patients, after general anaesthesia was induced via mask with a mixture of enflurane, $67 \%$ nitrous oxide and oxygen, tracheal intubation was performed without neuromuscular relaxants or other adjuvants. Subsequently, anaesthesia was maintained with end-tidal enflurane concentration of $1.0-2.0 \%$ and $67 \%$ nitrous oxide in oxygen. Phenylephrine $2 \mu \mathrm{g} \cdot \mathrm{kg}^{-1}$ was injected after a stable haemodynamic period of at least ten minutes had been obtained, while the patient was positioned supine throughout the study. Haemodynamic measurements were made at one-minute intervals for ten minutes after the injection of phenylephrine. Immediately after the last measurements, arterial blood was sampled and analysed for $\mathrm{pHa}$, carbon dioxide tension $\left(\mathrm{PaCO}_{2}\right)$, oxygen tension $\left(\mathrm{PaO}_{2}\right)$, and base excess with a selfcalibrating electrodes system (model 288, Corning, Medfield, MA). A precalibrated gas monitor (Capnomac ${ }^{\mathrm{TM}}$, Datex, Helsinki, Finland) was employed for gasometry.

Data were expressed as mean \pm SD. Mean blood pressure (MBP) was calculated as diastolic blood pressure (DBP) plus $1 / 3 \times$ (systolic blood pressure (SBP) - DBP). Statistical comparisons among groups were performed using two-way analysis of variance (ANOVA) followed by an unpaired Student's $t$ test with Bonferroni correc- 
TABLE I Patient characteristics and clonidine doses

\begin{tabular}{|c|c|c|c|c|c|}
\hline Group & Age (yr) & Weight $(\mathrm{kg})$ & Height $(\mathrm{cm})$ & $\operatorname{Sex}(F / M)$ & Clonidine dose $\left(\mu \mathrm{g} \cdot \mathrm{kg}^{-1}\right)$ \\
\hline \multicolumn{6}{|l|}{ Awake } \\
\hline Control $(n=20)$ & $45 \pm 13$ & $56 \pm 9$ & $156 \pm 7$ & $9 / 11$ & - \\
\hline Clonidine $(n=20)$ & $44 \pm 11$ & $56 \pm 10$ & $158 \pm 11$ & $10 / 10$ & $4.86 \pm 0.32$ \\
\hline \multicolumn{6}{|l|}{ Anaesthetized } \\
\hline Control $(n=20)$ & $46 \pm 9$ & $56 \pm 6$ & $157 \pm 8$ & $10 / 10$ & - \\
\hline Clonidine $(n=20)$ & $43 \pm 10$ & $58 \pm 10$ & $157 \pm 9$ & $10 / 10$ & $4.88 \pm 0.34$ \\
\hline
\end{tabular}

Values are mean $\pm \mathrm{SD}$.

TABLE 11 Haemodynamic responses to intravenous phenylephrine $2 \mu \mathrm{g} \cdot \mathrm{kg}^{-1}$ in awake patients

\begin{tabular}{|c|c|c|c|c|c|c|c|c|c|c|c|c|c|}
\hline \multirow[b]{2}{*}{ Group } & & \multirow[b]{2}{*}{ Baseline } & \multicolumn{10}{|c|}{ Time after phenylephrine (min) } & \multirow{2}{*}{$\begin{array}{l}\text { Duration of } \\
\text { responsest } \\
\text { (min) }\end{array}$} \\
\hline & & & 1 & 2 & 3 & 4 & 5 & 6 & 7 & 8 & 9 & 10 & \\
\hline \multirow{4}{*}{$\begin{array}{l}\text { Control } \\
(n=20)\end{array}$} & SBP & $125 \pm 14$ & $131 \pm 14^{*}$ & $142 \pm 18^{*}$ & $130 \pm 16$ & $123 \pm 12$ & $123 \pm 12$ & $121 \pm 11 *$ & $119 \pm 10^{*}$ & $120 \pm 10^{*}$ & $120 \pm 12^{*}$ & $120 \pm 10^{*}$ & $3.6 \pm 2.3$ \\
\hline & DBP & $70 \pm 11$ & $76 \pm 12 *$ & $78 \pm 14^{*}$ & $72 \pm 11$ & $67 \pm 11$ & $67 \pm 10$ & $65 \pm 9 *$ & $64 \pm 9 *$ & $64 \pm 9 *$ & $62 \pm 10^{*}$ & $65 \pm 10^{*}$ & $4.0 \pm 2.8$ \\
\hline & MBP & $88 \pm 12$ & $94 \pm 12 *$ & $99 \pm 15^{*}$ & $91 \pm 12$ & $86 \pm 11$ & $86 \pm 10$ & $83 \pm 9 *$ & $82 \pm 9 *$ & $83 \pm 9 *$ & $81 \pm 8 *$ & $83 \pm 10^{*}$ & $4.7 \pm 3.1$ \\
\hline & HR & $70 \pm 8$ & $62 \pm 9^{*}$ & $60 \pm 7^{*}$ & $64 \pm 7^{*}$ & $67 \pm 8^{*}$ & $68 \pm 9$ & $70 \pm 8$ & $70 \pm 8$ & $70 \pm 8$ & $70 \pm 8$ & $70 \pm 8$ & $4.6 \pm 3.0$ \\
\hline \multirow{4}{*}{$\begin{array}{l}\text { Clonidine } \\
(n=20)\end{array}$} & SBP & $108 \pm 14 \dagger$ & $117 \pm 21^{*}$ & $135 \pm 23^{*}$ & $127 \pm 19^{*}$ & $118 \pm 18 *$ & $115 \pm 15^{*}$ & $112 \pm 16$ & $110 \pm 15$ & $107 \pm 13$ & $107 \pm 14$ & $107 \pm 14$ & $5.9 \pm 2.7 \dagger$ \\
\hline & DBP & $61 \pm 11$ & $64 \pm 13^{*}$ & $77 \pm 14^{*}$ & $70 \pm 13^{*}$ & $63 \pm 13$ & $62 \pm 12$ & $60 \pm 11$ & $60 \pm 10$ & $58 \pm 10$ & $56 \pm 10^{*}$ & $56 \pm 9^{*}$ & $5.8 \pm 2.9$ \\
\hline & MBP & $76 \pm 12$ & $82 \pm 15^{*}$ & $=96 \pm 16^{*}$ & $89 \pm 15^{*}$ & $81 \pm 14$ & $80 \pm 12$ & $77 \pm 12$ & $76 \pm 12$ & $74 \pm 10$ & $73 \pm 11$ & $73 \pm 11$ & $6.0 \pm 3.1$ \\
\hline & HR & $64 \pm 12$ & $54 \pm 12^{*}$ & $52 \pm 9 *$ & $56 \pm 10^{*}$ & $60 \pm 12 *$ & * $61 \pm 13^{*}$ & $63 \pm 13$ & $63 \pm 12$ & $63 \pm 13$ & $63 \pm 13$ & $63 \pm 12$ & $7.3 \pm 3.0 \dagger$ \\
\hline
\end{tabular}

Values are mean $\pm \mathrm{SD} . \mathrm{SBP}=$ systolic blood pressure $(\mathrm{mmHg}) ; \mathrm{DBP}=$ diastolic blood pressure $(\mathrm{mmHg}) ; \mathrm{MBP}=\mathrm{mean}$ blood pressure $(\mathrm{mmHg}) ;$ $\mathrm{HR}=$ heart rate (beats $\cdot \mathrm{min}^{-1}$ ).

$* P<0.05$ versus baseline.

$\uparrow P<0.05$ versus control group.

†Defined as duration of changes in BPs above baseline values or changes in HR below baseline values following phenylephrine injection.

tions. The BP and HR responses to phenylephrine were analysed by using repeated-measures ANOVA (one-way ANOVA) followed by a paired Student's $t$ test for paired data in each group. Testing for the incidence of hypotension and bradycardia among groups was accomplished by chi-squared analysis. $P<0.05$ was considered the minimum level of statistical significance.

\section{Results}

There were no differences among the four groups of patients with respect to age, weight, height, and ratio of women to men (Table I). Clonidine doses in awake and anaesthetized patients of the clonidine group were 4.86 $\pm 0.32 \mu \mathrm{g} \cdot \mathrm{kg}^{-1}$ and $4.88 \pm 0.34 \mu \mathrm{g} \cdot \mathrm{kg}^{-1}$, respectively.

Baseline values of SBP in awake patients of the clonidine group were less than those in awake patients of the control group, whereas any differences in DBP, MBP and $H R$ between the two groups did not reach statistical significance (Table II). In awake patients of the control group, SBP increases above baseline values after intravenous phenylephrine lasted only for $3.6 \pm 2.3 \mathrm{~min}$, and thereafter SBP decreased below baseline values. In contrast, in awake patients of the clonidine group, SBP ele- vations were more prolonged (for $5.9 \pm 2.7 \mathrm{~min}, P<$ 0.05, Table II). The maximal changes in SBP and MBP from baseline values in the clonidine and control groups were $31.0 \pm 11.6$ and $17.5 \pm 9.0 \mathrm{mmHg}(P<0.01)$, and $19.8 \pm 6.7$ and $10.9 \pm 6.0 \mathrm{mmHg}(P<0.01)$, respectively. The average MBP values at the time of peak response following phenylephrine in awake patients of the clonidine group were greater than those of the control group (Figure 1, $26 \pm 7 \%$ vs $13 \pm 7 \% ; P<0.05$ ): In awake patients of the control and clonidine groups, HR reductions below baseline values after phenylephrine persisted for longer in the clonidine group than in the control group ( $P<0.05$, Table II). Thereafter, $\mathrm{HR}$ in both groups returned to baseline values during the remainder of study period.

In the comparison of anaesthetized patients of the control and clonidine groups, there were no differnces in the end-tidal concentration of enflurane for maintenance of general anaesthesia, infusion rate of lactated Ringer's solution before injection of phenylephrine, arterial blood gas values, and basal haemodynamic variables (Tables III and IV). In anaesthetized patients, the duration of BP increases above baseline values after intravenous phe- 
TABLE III End-tidal concentration of enflurane, infusion rate of crystalloid, and arterial blood gas values during general anaesthesia

\begin{tabular}{lllllll}
\hline & $\begin{array}{l}\text { End-tidal enflurane } \\
\text { concentration } \\
\text { Group }\end{array}$ & $\begin{array}{l}\text { Lactated Ringer's } \\
\text { solution } \\
\left(\mathrm{ml} \cdot \mathrm{kg}^{-1} \cdot \mathrm{hr}^{-1}\right)\end{array}$ & $p \mathrm{Ha}$ & $\begin{array}{l}\mathrm{PaCO}_{2} \\
(\mathrm{mmHg})\end{array}$ & $\begin{array}{l}\mathrm{PaO}_{2} \\
(\mathrm{mmHg})\end{array}$ & $\begin{array}{l}\mathrm{Base} \text { excess } \\
\left(\mathrm{mEq} \cdot \mathrm{L}^{-1}\right)\end{array}$ \\
\hline Control $(n=20)$ & $1.6 \pm 0.6$ & $9.2 \pm 1.2$ & $7.43 \pm 0.03$ & $33 \pm 2$ & $169 \pm 33$ & $0.8 \pm 2.1$ \\
Clonidine $(n=20)$ & $1.3 \pm 0.4$ & $9.3 \pm 1.7$ & $7.42 \pm 0.04$ & $34 \pm 4$ & $166 \pm 31$ & $0.6 \pm 2.5$ \\
\hline
\end{tabular}

Values are mean $\pm \mathrm{SD} . \mathrm{pHa}=$ arterial blood $\mathrm{pH} ; \mathrm{PaCO}_{2}=$ arterial $\mathrm{CO}_{2}$ tension; $\mathrm{PaO}_{2}=$ arterial $\mathrm{O}_{2}$ tension.

TABLE IV Haemodynamic responses to intravenous phenylephrine $2 \mu \mathrm{g} \cdot \mathrm{kg}^{-1}$ in patients anaesthetized with enflurane and nitrous oxide in oxyen

\begin{tabular}{|c|c|c|c|c|c|c|c|c|c|c|c|c|c|}
\hline \multirow[b]{2}{*}{ Group } & & \multirow[b]{2}{*}{ Baseline } & \multicolumn{10}{|c|}{ Time after phenylephrine (min) } & \multirow{2}{*}{$\begin{array}{l}\text { Duration of } \\
\text { responses } \neq \\
\text { (min) }\end{array}$} \\
\hline & & & $l$ & 2 & 3 & 4 & 5 & 6 & 7 & 8 & 9 & 10 & \\
\hline \multirow{4}{*}{$\begin{array}{l}\text { Control } \\
(n=20)\end{array}$} & SBP & $102 \pm 12$ & $112 \pm 20^{*}$ & $119 \pm 18^{*}$ & $112 \pm 18^{*}$ & $106 \pm 15$ & $104 \pm 14$ & $100 \pm 15$ & $99 \pm 14^{*}$ & $99 \pm 14^{*}$ & $99 \pm 14^{*}$ & $99 \pm 15^{*}$ & $5.5 \pm 2.8$ \\
\hline & DBP & $56 \pm 11$ & $63 \pm 14^{*}$ & $68 \pm 16^{*}$ & $61 \pm 14^{*}$ & $58 \pm 12$ & $56 \pm 12$ & $55 \pm 13$ & $54 \pm 13$ & $54 \pm 13$ & $55 \pm 12$ & $55 \pm 13$ & $5.7 \pm 3.1$ \\
\hline & MBP & $71 \pm 11$ & $79 \pm 16^{*}$ & $85 \pm 16^{*}$ & $78 \pm 15^{*}$ & $74 \pm 13^{*}$ & $72 \pm 12$ & $70 \pm 13$ & $69 \pm 13$ & $69 \pm 13$ & $70 \pm 12$ & $69 \pm 13$ & $5.7 \pm 3.1$ \\
\hline & $\mathrm{HR}$ & $62 \pm 5$ & $55 \pm 7^{*}$ & $55 \pm 5^{*}$ & $57 \pm 6^{*}$ & $58 \pm 6^{*}$ & $58 \pm 6^{*}$ & $59 \pm 6^{*}$ & $59 \pm 6^{*}$ & $59 \pm 6^{*}$ & $59 \pm 6^{*}$ & $59 \pm 6^{*}$ & $8.0 \pm 3.2$ \\
\hline \multirow{4}{*}{$\begin{array}{l}\text { Clonidine } \\
(n=20)\end{array}$} & SBP & $92 \pm 14$ & $98 \pm 17^{*}$ & $117 \pm 21^{*}$ & $114 \pm 21^{*}$ & $106 \pm 17^{*}$ & $102 \pm 14^{*}$ & $99 \pm 16^{*}$ & * $97 \pm 16$ & $93 \pm 13$ & $92 \pm 14$ & $89 \pm 14$ & $6.9 \pm 2.5$ \\
\hline & DBP & $49 \pm 11$ & $52 \pm 13$ & $66 \pm 13^{*}$ & $62 \pm 15^{*}$ & $57 \pm 12^{*}$ & $53 \pm 10$ & $50 \pm 9$ & $49 \pm 8$ & $46 \pm 8$ & $45 \pm 9$. & $45 \pm 7$ & $6.2 \pm 2.5$ \\
\hline & MBP & $63 \pm 12$ & $67 \pm 14$ & $83 \pm 16^{*}$ & $79 \pm 17^{*}$ & $73 \pm 13^{*}$ & $69 \pm 11^{*}$ & $66 \pm 11$ & $65 \pm 10$ & $62 \pm 9$ & $61 \pm 10$ & $59 \pm 9$ & $6.4 \pm 2.3$ \\
\hline & HR & $59 \pm 4$ & $56 \pm 4$ & $54 \pm 4^{*}$ & $55 \pm 4 *$ & $57 \pm 4^{*}$ & $57 \pm 4^{*}$ & $57 \pm 4^{*}$ & $59 \pm 4$ & $58 \pm 4$ & $59 \pm 4$ & $58 \pm 5$ & $5.5 \pm 2.9 \dagger$ \\
\hline
\end{tabular}

Values are mean $\pm \mathrm{SD}$. SBP = systolic blood pressure $(\mathrm{mmHg}) ; \mathrm{DBP}=$ diastolic blood pressure $(\mathrm{mmHg}) ; \mathrm{MBP}=$ mean blood pressure $(\mathrm{mmHg}) ;$ $\mathrm{HR}=$ heart rate $\left(\right.$ beats $\left.\cdot \min ^{-1}\right)$.

$* P<0.05$ versus baseline.

$\dagger P<0.05$ versus control group.

†Defined as duration of changes in BPs above baseline values or changes in HR below baseline values following phenylephrine injection.

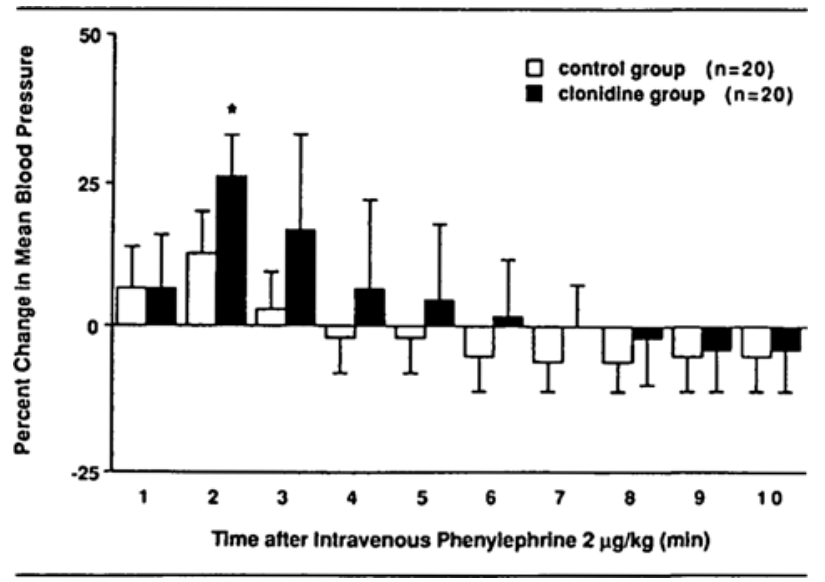

FIGURE 1 Percent changes ( $\pm S D$ ) in mean blood pressure after intravenous phenylephrine $2 \mu \mathrm{g} \cdot \mathrm{kg}^{-1}$ in awake patients receiving approximately $5 \mu \mathrm{g} \cdot \mathrm{kg}^{-1}$ clonidine po (clonidine group) or no premedication (control group). ${ }^{*} P<0.05$ between the two groups.

nylephrine was similar between groups (Table IV). The maximal changes in SBP and MBP from baseline values in the clonidine and control groups were $27.4 \pm 12.0$ and $17.2 \pm 8.9 \mathrm{mmHg}(P<0.05)$, and $19.9 \pm 9.1$ and $13.5 \pm 6.7 \mathrm{mmHg}(P=0.051)$, respectively. The magnitudes of the MBP increases at the time of peak response after phenylephrine in anaesthetized patients of the clonidine group were greater than those of the control group (Figure $2,32 \pm 5 \%$ vs $18 \pm 7 \% ; P<0.05$ ). In anaesthetized patients, HR decreases after phenylephrine were sustained for longer in the control group than in the clonidine group $(P<0.05$, Table IV). In the comparison of awake and anaesthetized patients in each group, the magnitudes of pressor responses to phenylephrine were not different, although they tended to be greater in anaesthetized patients than awake patients (Figures 1 and 2).

Hypotensive episodes (defined as SBP $<80 \mathrm{mmHg}$ ) before intravenous phenylephrine were found in one anaesthetized patient of the clonidine group, but this patient responded well to phenylephrine without showing bradycardia. There were, however, no differences in the incidence of hypotension between the control and clonidine groups. Bradycardia episodes (defined as $\mathrm{HR}<50$ beats $\cdot \min ^{-1}$ ) occurred immediately after intravenous 


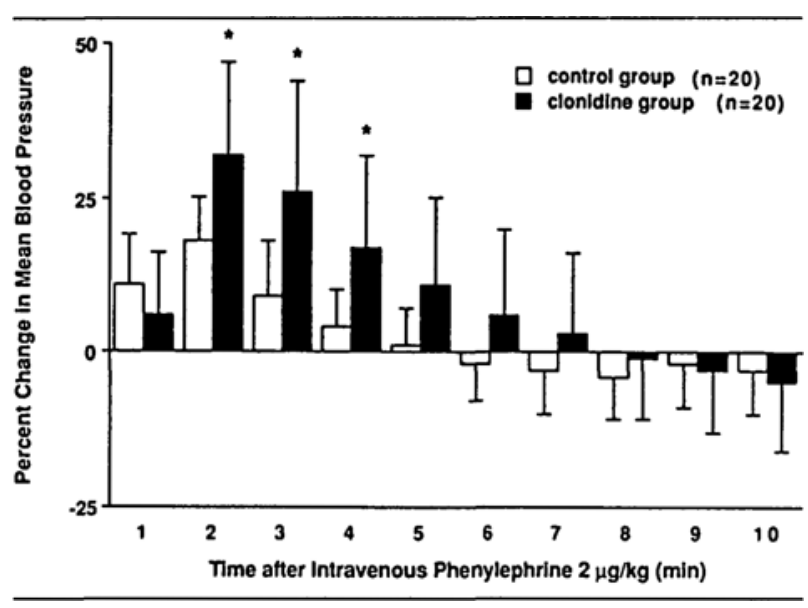

FIGURE 2 Percent changes $( \pm S D)$ in mean blood pressure after intravenous phenylephrine $2 \mu \mathrm{g} \cdot \mathrm{kg}^{-1}$ in anaesthetized patients receiving approximately $5 \mu \mathrm{g} \cdot \mathrm{kg}^{-1}$ clonidine po (clonidine group) or no premedication (control group). ${ }^{*} P<0.05$ between the two groups.

phenylephrine in 11 awake patients with clonidine medication $(55 \%)$ and in two awake patients without clonidine medication (10\%, $P<0.05$ ). During anaesthesia, bradycardia episodes were found in five and three patients of the clonidine and control groups, respectively $(P<$ 0.05 ). However, no patient developed severe bradycardia (HR $<40$ beats $\cdot \mathrm{min}^{-1}$ ) after phenylephrine in the current study, and HR returned to baseline values in all bradycardic patients without atropine treatment. In addition, none of the patients developed arrhythmias, severe hypertension after phenylephrine, or acute postoperative clonidine withdrawal syndrome. There were no other adverse reactions related to phenylephrine or clonidine or to interaction between the two agents.

\section{Discussion}

The major finding in the current study was that clonidine $5 \mu \mathrm{g} \cdot \mathrm{kg}^{-1}$ po as preanaesthetic medication augmented the pressor effect of phenylephrine $2 \mu \mathrm{g} \cdot \mathrm{kg}^{-1} \dot{\nu}$ in awake and anaesthetized patients. The magnitudes of pressor responses to phenylephrine were not altered by general anaesthetics in all the clonidine-treated or control patients. None of the patients receiving clonidine showed abnormally exaggerated pressor responses or severe bradycardia ( $\mathrm{HR}<40$ beats $\cdot \mathrm{min}^{-1}$ ) following phenylephrine in either the awake or the anaesthetized state.

Although clonidine in a dose of approximately 5 $\mu \mathrm{g} \cdot \mathrm{kg}^{-1}$ po has recently been used as part of a preanaesthetic regimen, ${ }^{1-7}$ several studies suggested that clonidine preanaesthetic medication may cause a greater incidence of hypotension or bradycardia. ${ }^{12,13}$ In the current study, only one anaesthetized patient given clonidine became hypotensive (SBP $<80 \mathrm{mmHg}$ ) prior to phenylephrine; however, this patient responded well to pheny- lephrine without developing bradycardia. Likewise, no severe bradycardia (HR $<40$ beats $\cdot \mathrm{min}^{-1}$ ) was noted following phenylephrine in any patient, though transient moderate bradycardia (HR $<50$ beats $\cdot \min ^{-1}$ ) developed in 11 clonidine-treated awake patients. Therefore, the administration of phenylephrine $2 \mu \mathrm{g} \cdot \mathrm{kg}^{-1} i \nu$ in the presence of oral clonidine medication in a dose of 5 $\mu \mathrm{g} \cdot \mathrm{kg}^{-1}$, seems not to be associated with serious adverse effects in surgical patients without any cardiovascular abnormalities and who are not receiving sympatholytic medication. A lower dose of clonidine may be appropriate especially in elderly patients to avoid hypotension or bradycardia: ${ }^{13}$ the latter is often resistant to treatment with atropine. ${ }^{6}$ Enhancement of pressor responses to phenylephrine $2 \mu \mathrm{g} \cdot \mathrm{kg}^{-1}$ following clonidine medication 5 $\mu \mathrm{g} \cdot \mathrm{kg}^{-1}$ in the current study is consistent with our previous reports ${ }^{4,5}$ showing that oral clonidine $5 \mu \mathrm{g} \cdot \mathrm{kg}^{-1}$ augmented the pressor responses to intravenous ephedrine $0.1 \mathrm{mg} \cdot \mathrm{kg}^{-1}$ in awake and anaesthetized patients. Although the precise mechanisms for the enhanced pressor effects of ephedrine have not been fully elucidated, our recent clinical studies demonstrated that clonidine augmented not only the pressor effect of ephedrine 0.1 $\mathrm{mg} \cdot \mathrm{kg}^{-1}$ without change in plasma catecholamine levels, ${ }^{5}$ but also the pressor response to norepinephrine 0.5 $\mu \mathrm{g} \cdot \mathrm{kg}^{-1} \dot{\nu}$ in patients anaesthetized with enflurane, nitrous oxide and oxygen (unpublished observation). These findings suggest that augmentation of the pressor responses to ephedrine or norepinephrine following clonidine medication is primarily attributed to enhanced sensitivity of tissue receptors to which ephedrine or norepinephrine binds, and/or potentiation of $\alpha$ adrenoceptor mediated vasoconstriction of clonidine and other vasoconstrictors. ${ }^{4,5}$ Similarly, based on these assumptions, an increased vasoconstrictive response to phenylephrine in patients receiving clonidine may account for the augmented pressor effect of phenylephrine following clonidine in the current study. Because there were no cardiac output or systemic vascular resistance data following phenylephrine in the current study, we cannot neglect the possibility that these enhanced pressor effects of vasopressors following clonidine are partly due to augmentation of the inotropic action mediated by $\alpha-$ adrenoceptors.

As far as we know, the pressor responses to phenylephrine, particularly in the presence of anaesthetic or other vasoactive agents affecting autonomic function, have never been studied extensively. Whether $\alpha_{1^{-}}$or $\alpha_{2^{-}}$ adrenoceptor-mediated vasoconstriction could be predominantly affected by volatile anaesthetics remains controversial in animal experiments. ${ }^{10,11,14}$ However, some recent reports in humans ${ }^{15,16}$ have shown that halothane ( $1 \%$ inspired) or isoflurane (mean end-tidal concentration 
of $1.8 \%$ ) had no influence upon the cardivascular responses to phenylephrine infusion $\left(30-50 \mu \mathrm{g} \cdot \mathrm{min}^{-1}\right)$ or bolus injection of phenylephrine (approximately 1.5 $\mu \mathrm{g} \cdot \mathrm{kg}^{-1}$ ). These results are in accord with the current study showing no differences in the vasopressor effects of phenylephrine between awake and anaesthetized patients with and without clonidine medication (Figures 1 and 2). In our previous report, the pressor effect of ephedrine was augmented by enflurane and nitrous oxide. These divergent results between the previous and current studies may be ascribed to the different type of vasopressors (direct- vs indirect-acting, or selective $\alpha_{1}$ agonist vs non-selective $\alpha_{1}$ and $\beta_{1}$ agonist). Based on the report that enflurane and nitrous oxide anaesthesia suppresses arterial baroreceptor functions in humans, ${ }^{17}$ it is assumed that the pressor effect of phenylephrine also could be greater during anaesthesia. However, the magnitudes of MBP changes following phenylephrine were similar in the awake and anaesthetized states in the current study, despite the slightly prolonged pressor responses to phenylephrine in anaesthetized patients of both groups compared to those in awake patients (Figures 1 and 2; Tables II and IV). Since baroreflex sensitivity is reported to be enhanced following administration of clonidine in both humans ${ }^{8,18}$ and animals, ${ }^{19,20}$ clonidine may have alleviated enflurane and nitrous oxide anaesthesia-induced suppression of arterial baroreceptor reflexes. Nevertheless, the current results could not be explained solely by clonidine-induced alterations in baroreflex function, because we also found little anaesthetic effect on the pressor response to phenylephrine in the patients receiving no clonidine. Indeed, some clinical investigations have reported no potentiation of the baroreflex responses following clonidine. ${ }^{21,22}$

In conclusion, clonidine $5 \mu \mathrm{g} \cdot \mathrm{kg}^{-1}$ po preanaesthetic medication augmented the pressor responses to phenylephrine $2 \mu \mathrm{g} \cdot \mathrm{kg}^{-1}$ iv in awake and anaesthetized patients; the magnitude of pressor response was not altered by general anaesthetics in patients with and without clonidine medication. This finding implies that restoration of blood pressure can be achieved effectively by phenylephrine in hypotensive patients with clonidine premedication. Concerning the adverse interaction between $\alpha_{1}$ - and $\alpha_{2}$ agonists, no patient receiving clonidine showed abnormally exaggerated pressor responses or severe bradycardia (HR $<40$ beats $\cdot$ min $^{-1}$ ) after injection of phenylephrine in the current study. However, lower doses of clonidine may be recommended especially in elderly patients or patients receiving sympatholytic drugs to avoid profound hypotension or bradycardia. Otherwise, another vasopressor with $\alpha_{1}$ and $\beta_{1}$ adrenergic activities may be appropriate for the treatment of hypotension in patients given a large dose of clonidine.

\section{References}

1 Ghignone M, Quintin L, Duke PC, Kehler CH, Calvillo $O$. Effects of clonidine on narcotic requirements and hemodynamic response during induction of fentanyl anesthesia and endotracheal intubation. Anesthesiology 1986; 64: 36-42.

2 Ghignone $M$, Calvillo $O$, Quintin $L$. Anesthesia and hypertension: the effect of clonidine on perioperative hemodynamics and isoflurane requirements. Anesthesiology 1987; 67: 3-10.

3 Ghignone $M$, Noe $C$, Calvillo O, Quintin L. Anesthesia for ophthalmic surgery in the elderly: the effects of clonidine on intraocular pressure, perioperative hemodynamics, and anesthetic requirement. Anesthesiology 1988; 68: 707-16.

4 Nishikawa T, Kimura T, Taguchi N, Dohi S. Oral clonidine preanesthetic medication augments the pressor responses to intravenous ephedrine in awake or anesthetized patients. Anesthesiology 1991; 74: 705-10.

5 Tanaka $M$, Nishikawa T. Enhanced pressor response to intravenous ephedrine following oral clonidine premedication. Anesthesiology 1993; 79: A78.

6 Nishikawa T, Dohi S. Oral clonidine blunts the heart rate response to intravenous atropine in humans. Anesthesiology 1991; 75: 217-22.

7 Nishikawa T, Kimura T, Ikemura A, Iwai R, Sakaguchi $M$, Goyagi $T$. The effects of preanesthetic oral clonidine upon heart rate response to intravenous atropine in patients during general anesthesia. Masui 1992; 41: 1450-4.

8 Guthrie GP Jr, Kotchen TA. Effects of oral clonidine on baroreflex function in patients with essential hypertension. Chest 1983; 83: 327-8.

9 Schümann $H$-J, Endoh $M . \alpha$-adrenoceptors in the ventricular myocardium: clonidine, naphazoline and methoxamine as partial $\alpha$-agonists exerting a competitive dualism in action to phenylephrine. Eur J Pharmacol 1976; 36: 413-21.

10 Kenny D, Pelc LR, Brooks HL, Kampine JP, Schmeling $W T$, Warltier $D C$. Alterations of alpha ${ }_{1}$ and $\mathrm{alpha}_{2}$ adrenoceptor-mediated pressor responses by halothane and isoflurane anesthesia. Anesthesiology 1989; 71: 224-34.

11 Larach DR, Schuler HG, Derr JA, Larach MG, Hensley FA Jr., Zelis $R$. Halothane selectively attenuates $\alpha_{2}$ adrenoceptor mediated vasoconstriction, in vivo and in vitro. Anesthesiology 1987; 66: 781-91.

12 Engelman E, Lipszyc M, Gilbart E, et al. Effects of clonidine on anesthetic drug requirements and hemodynamic response during aortic surgery. Anesthesiology 1989; 71 : 178-87.

13 Filos KS, Patroni O, Goudas LC, Bosas O, Kassaras A, Gartaganis $S$. A dose-response study of orally administered clonidine as premedication in the elderly: evaluating hemodynamic safety. Anesth Analg 1993; 77: 1185-92.

14 Sprague DH, Yang JC, Ngai SH. Effects of isoflurane and 
halothane on contractility and the cyclic 3',5'-adenosine monophosphate system in the rat aorta. Anesthesiology 1974; 40: 162-7.

15 Grum DF, Azmy SS. Halothane anaesthesia does not modify the cardiovascular response to phenylephrine in man. Can J Anaesth 1990; 37: 873-7.

16 Schwinn DA, McIntyre RW, Reves JG. Isoflurane-induced vasodilation: role of the $\alpha$-adrenergic nervous system. Anesth Analg 1990; 71: 451-9.

17 Takeshima $R$, Dohi $S$. Comparison of arterial baroreflex function in humans anesthetized with enflurane or isoflurane. Anesth Analg 1989; 69: 284-90.

18 Harron DWG, Riddell JG, Shanks RG. Effects of azepexole and clonidine on baroreceptor mediated reflex bradycardia and physiological tremor in man. Br J Clin Pharmacol 1985; 20: 431-6.

19 Korner PI, Oliver JR, Sleight P, Chalmers JP, Robinson $J S$. Effects of clonidine on the baroreceptor-heart rate reflex and on single aortic baroreceptor fibre discharge. Eur $\mathbf{J}$ Pharmacol 1974; 28: 189-98.

20 Korner PI, Oliver JR, Sleight P, Robinson JS, Chalmers $J P$. Assessment of cardiac autonomic excitability in renal hypertensive rabbits using clonidine-induced resetting of the baroreceptor-heart rate reflex. Eur J Pharmacol 1975; 33: 353-62.

21 Mancia G, Ferrari A, Gregorini $L$, Zanchetti A. Clonidine and carotid baroreflex in essential hypertension. Hypertension 1979; 1: 362-70.

22 Muzi M, Goff DR, Kampine JP, Roerig DL, Eben TJ. Clonidine reduces sympathetic activity but maintains baroreflex responses in normotensive humans. Anesthesiology 1992; 77: 864-71. 